\title{
Torulopsis apis var. galacta var. nov.
}

\author{
W. I. GOLUBEV AND INNA P. BAB'EVA \\ Institute of Biochemistry and Physiology of Microorganisms, U.S.S.R. Academy of Sciences, Pushchino, and \\ Faculty of Soil Science, Moscow State University, Moscow, U.S.S.R.
}

\begin{abstract}
A description has been given of a new variety of yeast associated with the ants of the group Formica rufa L. Torulopsis apis var. galacta differs from T. apis by its spheroidal cell shape and its inability (or very weak ability) to assimilate raffinose and to grow in vitamin-free medium. In addition, it was found that the type strain $T$. apis produces primitive pseudomycelium.
\end{abstract}

In the report on the yeast species associated with ants of the group Formica rufa (1), reference was made to an asporogenous yeast which was discovered on cocoons. During the course of subsequent microbiological study on anthills, this yeast was isolated repeatedly, although it was never again found in large numbers. Other than on cocoons, it was found on the material of the inner cone of anthills and in the intestine of females.

This yeast is similar in its characteristics to Torulopsis apis Lavie ex van Uden et VidalLeiria (4) isolated from bees, but it cannot be identified with this species, mainly because of morphological differences. The following description of the new variety, $T$. apis var. galacta, is based on the study of 14 strains.

\section{MATERIALS AND METHODS}

Methods for isolation of yeasts from anthills have been given previously (1).

The description of the new variety is based on the standard methods employed in yeast taxonomy (5). For comparison, the type strain of $T$. apis BKM Y1538 (CBS 2674) was used.

The extraction of deoxyribonucleic acid (DNA) and chemical determination of base composition were carried out by Vanushin's modification of the method of Schmidt and Thanhauser (7).

\section{DESCRIPTION}

Torulopsis apis Lavie ex van Uden et VidalLeiria var. galacta Golubev et Bab'eva nov. var.

Haec varietas a specie differt: Cellulae rotundae. In malto agaro cultura (post unum mensem, $20^{\circ} \mathrm{C}$ ) alba. Pseudomycelium non format. Raffinosum non assimilantur (interdum exigue). Vitaminae additae necessariae sunt.

Typus culture: IBPhM Y-708 in collectione Instituti Biochemiae et Physiologie Microorganismorum Acad. Sci. URSS (Pushchino) conservatur, isolata ex pupulis Formica rufa L., 1970.

Growth in liquid media (yeast morphology medium [Difco], glucose-yeast extract-peptone water, or malt extract): After 3 days at $25^{\circ} \mathrm{C}$ the cells are spheroidal, 2 to $4.5 \mu \mathrm{m}$, single, in pairs, small clusters. The budding is multilateral; several buds may be present on the mother cell at the same time. No capsule demonstrable.

After 1 month at $20^{\circ} \mathrm{C}$ a sediment and a thin ring are present.

Growth on solid media (yeast morphology agar [Difco], glucose-yeast extract-peptone agar, or malt agar): After 3 days at $25^{\circ} \mathrm{C}$ the cells are of the same shape as in liquid media, 1.6 to 4 (rarely up to $6 \mu \mathrm{m}$ ) (Fig. 1).

After 1 month at $20^{\circ} \mathrm{C}$ the streak cultures are pasty, white, mat, smooth, slightly wrinkled on the periphery. The margin is entire.

Growth on malt gelatin: After 1 month at $17^{\circ} \mathrm{C}$ the colony is white, dull, pasty, smooth, slightly convex. The margin is entire. Gelatin is not liquefied.

Slide cultures on yeast morphology agar (Difco), cornmeal agar, and potato-glucose agar: Neither pseudomycelium nor true mycelium is produced.

Ascospore, ballistospore and teliospore formation: Not observed in single and mixed cultures.

Fermentation: Absent.

Assimilation of carbon compounds: Glucose, +; galactose, + weak; L-sorbose, - or + very weak; sucrose, + weak; maltose, -; cellobiose, - ; trehalose, -; lactose, -; melibiose, -; raffinose, - or + very weak; melezitose, -; inulin, -; soluble starch, -; D-xylose, -; L-arabinose, -; D-arabinose, -; D-ribose, -; L-rhamnose, -; ethanol, -; glycerol, + or weak; erythritol, -; ribitol, -; galactitol, -; D-mannitol, +; D-glucitol, + ; $\alpha$-methyl-D-glucoside, -; salicin, -; DL-lactic acid,..-; succinic acid, + weak; citric acid, -; i-inositol, -; glucuronic acid, -.

Splitting of arbutin: Negative.

Assimilation of potassium nitrate: Negative.

Urease activity: Negative. 
Formation of starch-like material: Absent. Growth on vitamin-free medium: Absent.

Growth at $37^{\circ} \mathrm{C}$ : Absent.

Acid formation on chalk agar: Absent.

Growth on $50 \%$ (wt/wt) glucose-yeast extract agar: Absent. Slow growth on $35 \%$ glucose.

Maximum concentration of sodium chloride allowing slow and weak growth: 5 to $6 \%$.

Guanine-plus-cytosine content in nuclear DNA: $46.0 \pm 0.5 \mathrm{~mol} \%$.

Etymology: galacta from the L. adj., milkwhite; referring to the color of the streak culture.

The type culture is IBPhM Y-708. It has been deposited in the collection of microorganisms, Institute of Biochemistry and Physiological Microorganisms, U.S.S.R. Academy of Sciences, Pushchino, Moscow region, U.S.S.R. This culture was isolated from cocoons of Formica rufa L., 1970.

\section{DISCUSSION}

The new yeast belongs to the group of organisms of the genus Torulopsis Berlese unable to utilize nitrate and to ferment any sugars. This group has been enlarged in recent years mainly by descriptions of new species associated with various insects $(2,6)$.

The absence of urease activity, guanine-pluscytosine $(\mathrm{G}+\mathrm{C})$ content, and the cell wall structure (V. V. Dmitriev, personal communication) strongly suggest that $T$. apis var. gal$a c t a$ is an ascomycetous yeast. The $\mathrm{G}+\mathrm{C}$ value for the new variety is close to that for $T$. apis $48.8 \mathrm{~mol} \%$ (3).

$T$. apis var. galacta and $T$. apis show great similarity in their carbon assimilation tests. However, it would appear feasible to distinguish them on the basis of raffinose utilization and the ability to grow in vitamin-free medium. Both T. apis var. galacta and T. apis BKM Y-1538 utilize succinic acid weakly.

In contrast to their close physiological similarity, T. apis and T. apis var. galacta clearly differ in morphology. The cells of the former are oval (Fig. 2), whereas the cells of the latter are spheroidal (Fig. 1). The difference in the shape of cells is sharper on glycerol and in aging cultures. Moreover, the type strain of $T$. apis was found to form rudimentary pseudomycelium (Fig. 3), unlike that of T. apis var. galacta. In addition, the streak cultures of the

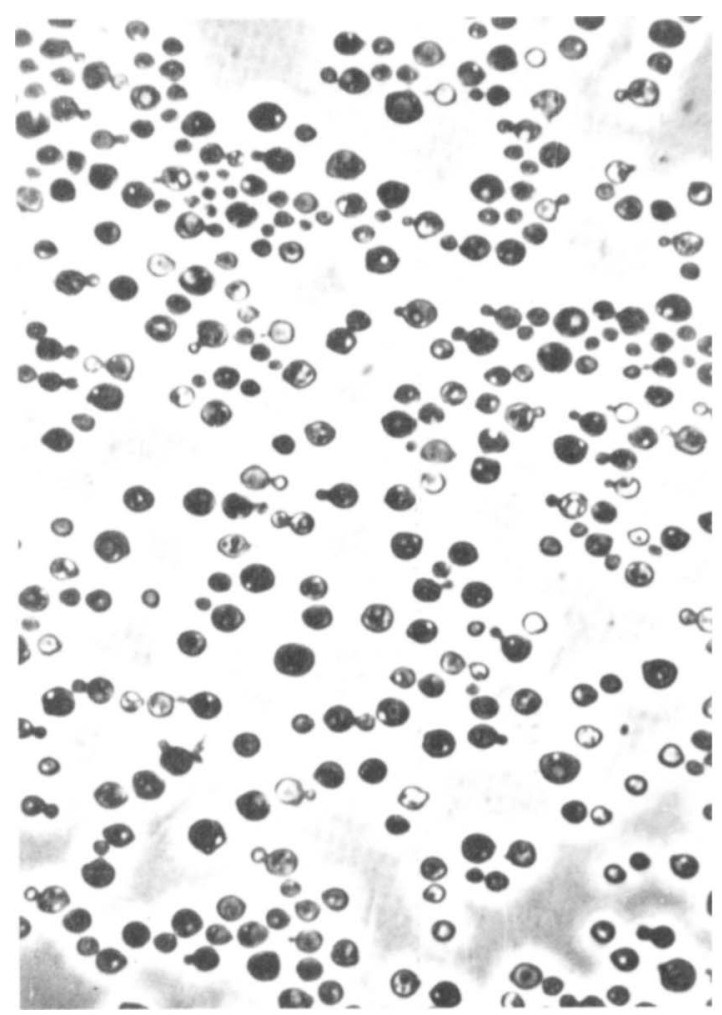

FIG. 1. Torulopsis apis var. galacta IBPhM Y708 (morphology agar, $20^{\circ} \mathrm{C}, 3$ days, phase contrast, magnification $\times 900$ ).

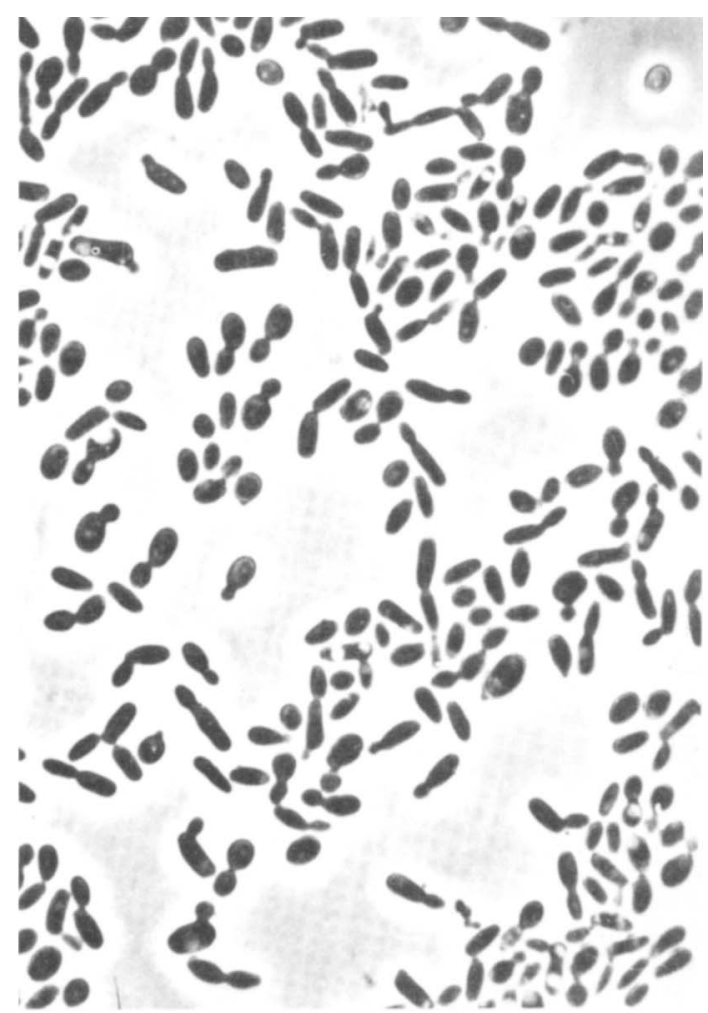

FIG. 2. Torulopsis apis BKM Y-1538 (morphology agar, $20^{\circ} \mathrm{C}, 3$ days, phase contrast, magnification $\times 900$ ). 


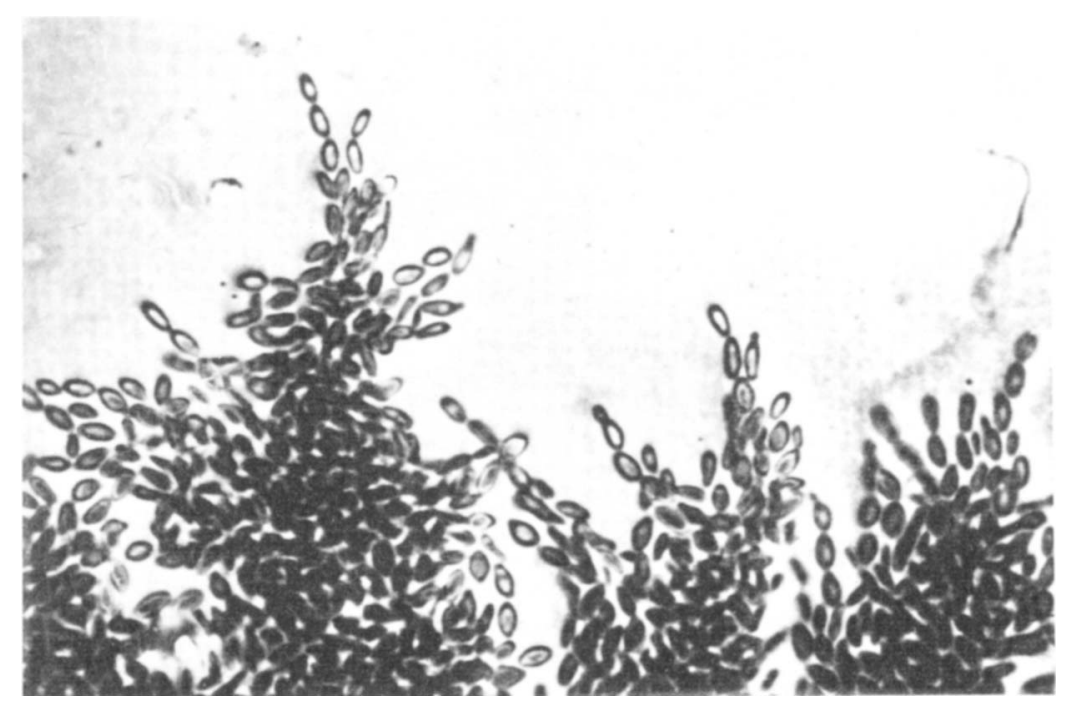

Fig. 3. Pseudomycelium of Torulopsis apis BKM Y-1538 (slide culture on morphology agar, $20^{\circ} \mathrm{C}, 10$ days, phase contrast, magnification $\times 900$, stained with cotton blue).

latter remain white after 1 month, but the culture of $T$. apis becomes light brown and later darkens even more. The above-mentioned differences and the great similarity of these yeasts allow us to consider our isolates to be a new variety of $T$. apis. Production of rudimentary pseudomycelium is obviously of little or no value for separation and, therefore, we are not proposing to transfer $T$. apis to the genus Candida Berkhout or to consider the new yeast a separate species.

\section{REPRINT REQUESTS}

Address reprint requests to: $\mathrm{Dr}$. W. I. Golubev, Institute of Biochemistry and Physiology of Microorganisms, U.S.S.R. Academy of Sciences, Pushchino, U.S.S.R.

\section{LITERATURE CITED}

1. Golubev, W. I., and I. P. Bab'eva. 1972. The yeasts of the genus Debaryomyces Klöck. In the ant-hills of the ants of the group Formica rufa. Ekologia 1:78-82.

2. Jurzitza, G. 1970 . Über Isolering, Kultur und Taxonomie einiger Anobiidensymbionten (Insecta, Coleoptera). Arch. Mikrobiol. 72:203-222.

3. Stenderup, A., S. A. Meyer, A. L. Bak, and C. Christiansen. 1972. Taxonomy of Candida and Torulopsis, p. 793-795. In Fermentation technology today. Proceedings of the IVth International Fermentation Symposium, Kyoto.

4. van Uden, N., and M. Vidal-Leiria. 1970. The genus Torulopsis Berlese, p. 1235-1308. In J. Lodder (ed.), The yeasts. A taxonomic study. North Holland Publishing Co., Amsterdam.

5. van der Walt, J. P. 1970. Criteria and methods in yeast classification, p. 34-113. In J. Lodder (ed.), The yeasts. A taxonomic study. North Holland Publishing Co., Amsterdam.

6. van der Walt, J. P., D. B. Scott, and W. C. van der Klift. 1971. Five new Torulopsis species from South African insect sources. Antonie van Leeuwenhoek $J$. Microbiol. Serol. 37:461-471.

7. Vanushin, B. F. 1964. The determination of nucleic acid base composition, p. 236-250. In Modern methods in biochemistry, vol. 1. Moscow. 